\title{
Byatt, Fiction and Biofiction
}

\author{
Max Saunders
}

HCM 7: 87-102

DOI: $10.18352 / \mathrm{hcm} .543$

\begin{abstract}
A. S. Byatt's fiction is much possessed by 'lives' - not only the lives of her characters, but the ideas of the biographies of those characters, and of characters as biographers. The essay will explore the relation between fiction, biography and autobiography in her work, taking in such topics as portraiture, myth, creation and reading. It will ask why a novelist who has written about earlier historical periods has eschewed one of the defining devices of the historical novel - and postmodern biofiction - of using real historical figures as characters.
\end{abstract}

Keywords: biofiction, biographic metafiction, fiction, fictional literary works, interiority, invention, life writing, meta-biofiction, portraiture, reading

\section{Introduction}

A. S. Byatt's fiction is much possessed by 'lives' - by acts of biography. It is her best-known novel Possession: A Romance (1990) which brings this out most clearly, with its double, parallel, plots, of the lives of the Victorian writers, Randolph Henry Ash and Christabel LaMotte, on the one hand, whose relationship is gradually brought to light; and on the other hand, the story of their two biographers, who are drawn to each other through their biographical interests, and whose biographical quest combines and propels both plots. ${ }^{\mathrm{I}}$ 
The biography that takes the form of a quest is a modernist invention, ${ }^{2}$ like The Quest for Corvo (1934), by A. J. A. Symons, in which the biographer's search for the truth of the subject becomes part of the story, or even the main story. It is a model that has been developed by Richard Holmes in our time, in books like Shelley: The Pursuit (I974), or Footsteps: Adventures of a Romantic Biographer (I985). This form presents a real biographer - Symons or Holmes - chasing after a real subject - Corvo, Shelley, Stevenson, etc. It represents a biographical equivalent of the shift in fiction from the assumed omniscience and objectivity of the narrator of classic realism to modernism's exploration of the limited or unreliable narrator: himself or herself a character in the story, which thereby becomes double-articulated, relativistic, provisional; subject to a multiplicity of interpretations.

Of course classic realism was already (if not always) experimenting with such ambiguities; nowhere more so than in Flaubert's dextrous slipping in and out of style indirect libre, in which characters are presented in terms of their own thought processes and vocabularies, but in the grammar of externalised narrative (using the third person and past tenses). The insight into the interiority of the characters invites empathy, but the narrative voice supplements this interiority with an implicit view from outside, which tends to ironize the characters' views of themselves. Emma Bovary's passions thus become poignant and tragic, yet at the same time banal and absurd. At the end of the story 'Un Coeur Simple' from Flaubert's Trois Contes (I877), the dying servant Felicité has a vision of her dead parrot Loulou resurrected as the Holy Ghost. For her it is a beatific vision, a joyful confirmation of the love she has vested in her only companion; and to the extent that readers can share that view, it testifies to her 'simple heart' - her purity of soul. Yet from another point of view it is grotesque: a fetishistic displacement of her affections due to the emotional suppressions of her single and subservient life; a category error; an absurdity; the product of a simple mind.

Flaubert's story provided the pre-text for one of the first great postmodern novels to play with the conventions of biography: Julian Barnes's Flaubert's Parrot (I984). In this case the form is one in which a fictional narrator pursues a real biographical subject. Barnes's narrator, Geoffrey Braithwaite, is in pursuit of the biographical truth of Gustave Flaubert, and becomes fascinated by the existence of two stuffed parrots in museums, both of which are claimed as the 'original' 
which inspired the story. Braithwaite learns that there are many more. In a characteristic postmodern move, the quest to relate fictional elements to their biographical sources is problematized, suggesting that reality or biography or history cannot be known outside stories, but only grasped through fictions. ${ }^{3}$

\section{Biographic Metafiction}

A. S. Byatt's stroke of genius in Possession is to take this development a stage further: to fictionalise the whole arrangement: not just the biographers, Roland Michell and Maud Bailey; but their subjects too. There has been much speculation about Ash's indebtedness to Browning or Tennyson; or LaMotte's to Christina Rossetti. But the point is that they are not simply pseudonyms for real figures. If they were, Byatt might have been able to quote passages from those writers. But - and this constituted the real ingenuity of the conception - she does not proceed like some postmodernists, such as Borges, by inventing wonderfully suggestive titles for non-existent works. Instead, she writes examples of the poetry and prose romances and letters of these fictional writers for them. In other words, she does not just fictionalize biographer and subject, but the biographer's sources too.

In a study of the relations between autobiography, biography and fiction, I have argued that fictional engagements with life writing "can be understood as a strand of what Linda Hutcheon defines as "historiographic metafiction", focusing on the representations of individual life-stories rather than on representations of historical crises or trauma.' ${ }^{4}$ What Hutcheon means by historiographic metafiction are 'those well-known and popular novels which are both intensely self-reflexive and yet paradoxically also lay claim to historical events and personages'; 5 and she analyses them in The Politics of Postmodernism in these terms:

Facts are events to which we have given meaning [...] Postmodern fiction often thematizes this process of turning events into facts through the filtering and interpreting of archival documents $[\ldots]$ in historiographic metafiction the very process of turning events into facts through the interpretation of archival evidence is shown to be a process of turning the traces of the past (our only access to those events today) into historical representation. ${ }^{6}$ 
So work of this kind by Ian McEwan, say, or Graham Swift, has real historical events, plus inserted fictional characters whose historiographical processes make the history real for us; but through fictional means. Of course a writer like McEwan plays with this by making Briony, the narrator of Atonement, an unreliable fictionist rather than historian. That may mean her characters did not actually behave as her narrative says; but it does not affect the existential status of the Second World War.

But what happens to historiographic metafiction when the history being fictionalised is personal history: life writing: biography or autobiography? What if your narrative is about a life or group of lives - as they often are? Not least because those historical traces so important for Hutcheon's argument - archival documents, testimony of witnesses come down to us, in part, through forms of life-writing: letters, diaries, journals, memoirs, interviews, autobiographies.

In such cases, the real which the focus on historiographic process brings to light is not the reality of history, but of individuals; and specifically, the reality of their interiority - precisely that aspect of individuals least likely (before the advent of internet-driven celebrity confessional culture) to documented in the public sphere. Possession is not so much concerned with world-historical events as with biographical stories and processes. It could thus be taxonomized as 'biographic metafiction'?

It still seems to me true that biographic metafiction (like Possession) shares with historiographic metafiction an interest in how historical narratives come into being; but that it provides a narrative of the history of a life (or group of lives) rather than of a historical situation. However, the varieties of biographic metafiction and the implications of the form warrant further elaboration (my focus in Self Impression was on fictionalizations of autobiography).

The metafictionality in the combination is crucial. Biographical metafiction like Possession is decidedly not an example of the biographical fiction, or biofiction, as it is now often termed, which takes real historical figures and places them in a novel. Take, for example, the extraordinary profusion of novels about Henry James that appeared in or around 2004, by Emma Tennant, Colm Tóibín, David Lodge, and others. ${ }^{8}$ They were about writing, certainly; about being an author - how could they not be? They used biographies, letters, memoirs, even novels, as sources. 
But they weren't dramatizing the process of biographical exploration by which they arrived at their presentations of James.

What they were perhaps doing, was reflecting on their own writing processes. So a 'meta' element enters into the equation through the parallel between their own lives as novelists, and the writer's life they are fictionalizing. That is to say, there is an element of the autobiographical in the biographical writing (as there always is). But that is a limited sense of 'meta'. The writers are being self-aware; demonstrating awareness of how their own projects relate to those of their subjects. What they are not doing is referring to, or playing with, the conventions of the genres of biography and fiction to the same extent that metafiction does. Thus rather than constituting a meta-fictional effect - something which would bring out the fictionality of the auto/biographical process - or a meta-biographical effect - which would thematise the biographical quest or process - such fictions gain their effects by superimposing two orders of reality. (These distinctions produce some ungainly jargon terms, and I do not expect anyone to want to use 'meta-auto/biofiction' or 'metabiofiction' as handy labels. But hopefully they make the point about what kind of writing this is, and why Possession is different.) They overlay the historical, biographical record of Henry James with their own narratives, using the techniques of impressionist and modernist fiction (such as stream of consciousness, interior monologue, free indirect style, and an episodic or epiphanic structure) to imagine the reality of precisely those areas missing from the received records: the private lives of intimacy, sexuality, homosexuality, envy, humiliation etc. ${ }^{9}$

In Possession, by contrast, though there is an extraordinary empathy with the Victorian male and female writers, there is very little identification with them, of the kind you get when Lodge or Tóibín give James's thought processes a more modern and less convoluted syntax than James's own writing. It is their differences from us, and from A. S. Byatt, that strike us more than their similarities.

\section{Invention}

Biofiction is not as new as its new-fangled name sometimes tries to suggest. It used to be called biographie romancé, as practised by writers like Emil Ludwig between the wars, and defined sternly by the Oxford 
Companion to German Literature as a form 'in which much carefully gathered source material was fused and presented in a manner more appropriate to fiction'. ${ }^{\text {Io }}$ It is a form which does not show you the biographer going over the sources to try to reconstruct the subject; instead it makes up conversations, interior monologues, and dramatized vignettes all silently based upon those sources. Whereas Byatt not only creates the subjects - Ash and LaMotte - but famously also makes up the sources too.

This produces something very curious. In a biofiction, Henry James, say, is recognisable as a real historical person. We may have the sense that it is a particular interpretation of him; as with Tóibín's version which inclines towards the still-controversial view of James as queer. Such an interpretation gives the book the quality of a thought experiment: what if James's emotional life really had been like this? How would it have affected his ways of thinking and experiencing?

In a historiographical metafiction like Salman Rushdie's Midnight's Children (I98I) the historical event of Indian Independence is a given. How it is given is not the way a historian would give it, certainly. It is more magical, perplexing, beautiful, contradictory, and so on. But its historical existence is neither challenged nor suspended; it remains demonstrable.

Yet in biographical metafiction like Possession, though there is a historical context - Victorian proprieties about relationships - the background of historical events stays in the background. In the foreground are the subjects of biographies who did not in fact exist. Nonetheless, we have the meticulous documenting of their existence, and of the quest of their existence by the meticulously described biographers - who do not really exist either. It is that paradoxical combination which is so distinctive about biographical metafiction as opposed to its historiographical cousin: on the one hand, the detailed documentation; on the other, the fictionality of the subject or subjects being documented. In fact it is the converse of the historiographical version. Where that may use real documents to fictionalize real characters, Byatt's biographical metafiction in Possession creates fictional documents to ground the existences of fictional characters.

Where historiographical metafiction and biofiction get their piquancy from the jarring valencies of history and novel, in biographical metafiction there is no veridical history as such to play against. There is much 
more scope for invention. The biographer character or characters are invented. The subject of the biography is invented. And therefore any sources have to be invented too. That range of invention - and especially the range of invented sources within it - is what so impresses many readers of Possession, including this one.

It is also what distinguishes Possession from most previous instances of biographical metafiction as well. There were, certainly, earlier novels presenting the figure of the biographer engaged in the biographical process. In Jean-Paul Sartre's 1938 novel La Nausée, the central character Antoine Roquentin is researching a biography of a minor French aristocrat of the eighteenth century, the Marquis de Rollebon. The Marquis is presumably a fictional personage (there seems to be no trace of him other than in Sartre's novel). Though it is curious that hardly any commentator seems to think that matters. Roquentin ends up abandoning biography for fiction. This might appear a surprising conclusion for a philosopher. Though given that the novel is presented in the form of Roquentin's diary, it might make us suspect that the fiction he is proposing to write might well be the diary narrative we have been reading.

Nabokov's The Real Life of Sebastian Knight (I94I) anticipated many of the later possible moves of the genre. His narrator, 'V.', is researching the biography of his famous half-brother, a novelist born in Russia who writes in English. It takes the form of a quest biography, but leaves us with the suggestion that V. is Sebastian Knight, just as his initial leaves us with the suggestion that V. is Vladimir Nabokov. Here too, the denouement reframes the preceding narrative. What first seemed like a series of frustrated attempts to find the biographical person in interviews with his contacts then appears to be a form of ludic autobiography, and finally to be neither biography nor autobiography at all, but a novel by the subject of both biography and autobiography.

In both these cases, there is powerful formal and philosophical ingenuity. They contain a plethora of fictional writer-figures - biographers, diarist, autobiographer, novelists. Yet what Sartre and Nabokov do not provide are the fictional sources of the biographical quests. We do not see de Rollebon's texts; we do not get to see any of the writing of Sebastian Knight's novel, of which Nabokov only gives us the teasing title: The Doubtful Asphodel. In neither novel is there anything to compare with Byatt's examples of Ash's verse, LaMotte's tales, or the letters of either. 


\section{'The Real Unknown Dead'}

That commitment to inventiveness leads us to another remarkable feature of Byatt's fictional dealings with history. Possession is very unlike a nineteenth century historical novel in many ways; not least because it does not stay in the nineteenth century, but runs its Victorian plot in parallel with its twentieth century one. But the Victorian part of it is itself unlike a nineteenth-century historical novel, because it does not do the thing Scott or Tolstoy do of introducing real great historical figures as walk-on parts - King Richard and Prince John in Ivanhoe, say; or Napoleon and General Kutuzov in War and Peace. Its main characters are leading writers in the period, but not real ones that are already familiar, like Browning and Rossetti.

This might seem something of a paradox, and is certainly worth dwelling on: A. S. Byatt sets fiction in past periods, or sets parts of her books there. She writes fiction about characters in history. Yet she is opposed to using real historical characters. What struck me about this when I first came across it, was how it bore on Ford Madox Ford's trilogy The Fifth Queen, about Henry VIII and Katharine Howard. Byatt clearly admires The Fifth Queen, writing an introduction to it, ${ }^{11}$ and writing about it in her book Portraits in Fiction. Ford's characters are not the Scott or Tolstoy history book cameos that are supposed to give an air of historical reality to the fictional Ivanhoes or Bezukhovs and Bolkonskys. They are themselves the protagonists, and Ford's aim is to give them the kind of psychological interiority of characters in a novel by Flaubert or Maupassant.

But A. S. Byatt eschews that approach in her own work too. In 2009 she said (in an interview with the organisers of the Booker prize): 'I really don't like the idea of "basing" a character on someone, and these days I don't like the idea of going into the mind of the real unknown dead'; adding: 'It feels like the appropriation of others' lives and privacy. Making other people up, which is a kind of attack on them'. ${ }^{12}$ It is also - we might note - what biographers do. She includes real figures in her fiction - Oscar Wilde appears in The Children's Book (2009), for example. But she points out that 'the novelist doesn't say what he thinks' ${ }^{13}$

She has also said that she would rather have 'her' Henry James than another writer's. But that could be taken as a reason for writing 
biofiction as much as for not writing it. I take it that what she means is that we all do have our own Henry James already, at least if we've read his books and letters and memoirs by people like Ford who actually knew him. To that extent she has already done the work of imagining James. So another's imagining of him will either seem redundant, or will jar with her own imagined James. Three thoughts appear to follow from these observations. First, there is a form of moralistic objection which might be raised, and which would go something like this: that the novelist has a responsibility to history and reality, and that working with the materials of history, including real historical personages in your fiction, is a way of keeping the imagination grounded in reality and truth. The theatre critic William Archer made such a criticism about implausible plots in Jacobean drama, saying the dramatists worked in a 'soft medium' ${ }^{14}$ Byatt's resistance to biofiction is of course anything but an assertion of this kind of trivial freedom. Archer's point is that the harder medium is the outlay of intellectual energy in the construction of a good modern work, and that of course is very much Byatt's hallmark.

It is precisely because of the value she sets on the art of invention that taking over ready-made historical figures does not seem to allow enough room for artistry. The second thought is thus that for such a writer the most important thing in a novel is invention. This is partly a matter of the novelist needing to create living characters: characters who persist in the imagination and memory as if they were real people. But creating living characters is not only a matter of flesh and blood and a few Dickensian mannerisms, or of adding some passionate entanglements. It is also - certainly for A. S. Byatt, who is also deeply interested in contemporary developments in cognitive science - a matter of creating living minds too; inventing the characters' worlds and styles of thought as well as behaviour. Their 'Passions of the Mind', in the title of her I99 I collection of essays. ${ }^{15}$ That is what feels problematic in the case of representing the interiority of real people. Besides any ethical qualm about intrusiveness, even if you were able to imagine Oscar Wilde's thoughts while avoiding the pitfalls of antiquarianism (making his thinking sound quaintly of its period), or presentism (making it sound anachronistically too like the thought of our time), or dramatic irony (imbuing it, again anachronistically, with a foreshadowing of his fate which comes from our hindsight rather than any foreknowledge he could have possessed); then even so, readers are likely to feel that 
though he might have had thoughts like these, nonetheless these actual thoughts come from another: the twenty-first century author, not the nineteenth-century one.

A. S. Byatt has written of the effect Iris Murdoch's essay 'Against Dryness' had on her, with its argument that literature is 'so important, especially since it has taken over some of the tasks formerly performed by philosophy. Through literature we can re-discover a sense of the density of our lives'. ${ }^{16}$ The third thought is to ask: what advantages might biofiction or biographical metafiction have for a writer attempting to capture that sense of 'the density of our lives'? Novels of ideas - or rather, novels taking the ideas of their characters seriously - do not have to take those forms. Think of Tolstoy again, for example. Surely he helps us 're-discover a sense of the density of our lives' just as effectively - possibly even more so - when he is writing about fictional characters like Pierre Bezukhov or Anna Karenina as when he is writing about Napoleon or General Kutuzov. So what does biofiction do that other forms of fiction cannot?

The distinction between biofiction and biographical metafiction seems crucial here too. I take it that Byatt's position would be that standard biofiction - fiction which tells us what was going on in the heads of the 'real unknown dead' (in that wonderful phrase) precisely does not summon up 'the density of our lives' but has the opposite, reductive effect, of denying what Murdoch calls 'the opacity of persons' ${ }^{17}$

Take the novel from 2000, The Biographer's Tale-A. S. Byatt's other most sustained and elaborated version of biographical metafiction. ${ }^{18}$ In it, the protagonist, Phineas G. Nanson, abandons a PhD on literary theory in favour of working on a biography from the I950s by a Yorkshireman called Scholes Destry-Scholes. The biography is the life of Elmer Bole, a Victorian explorer and polymath. As Hermione Lee put it in her Guardian review, Nanson:

gets possessed by Scholes on Bole, and decides to write a biography of the biographer. But he can't find out anything about him, except that he is a magical story-teller and is supposed to have drowned in the Maelstrom off Norway.

In his 'quest for Scholes', Phineas comes upon the following items: Scholes's lecture notes on biography [...] Then, three lengthy fragments of 'life-writing' by Scholes, one on Linnaeus, the eighteenth-century 
scientific writer and traveller, one on Galton, the nineteenth-century mental researcher, now damned for his views on eugenics, and one on Ibsen. 'A taxonomist, a statistician, a dramatist: students in their own ways of the connectedness of things and people.' Then, a shoebox of Scholes's leavings, including file cards of quotations by or about his three figures. Last, a report of his presumed drowning, with a photograph, not of his face, which Phineas has never seen, but of an empty boat. ${ }^{19}$

Clearly, what Byatt does not do here is parade real, dead, characters and try to make them seem 'known', putting words into their mouths and thoughts into their heads. That would be the standard biofictional approach. The subjects of Scholes's biographies mix real and fictional characters. The subject of the one he was able to finish, Bole, is fictional. The other three real subjects remain elusive. This novel is not a biographical novel but a metabiographical one, focusing on the process of writing biography. And there's a regression of reflecting mirrors here, since Destry's pursuit of his subjects is mirrored by Nanson's pursuit of him - and of course at another level by Byatt's writing of Nanson's story.

\section{'The Story of One's Story'}

There is another way of thinking of that trio of Linnaeus, Ibsen, and Galton. They are all concerned with the relation of individuals to groups or systems. Linnaeus, known as the "father of modern taxonomy', invented the binomial classification of genus and species. Ibsen invented living characters tangled in the webs of family and society. Galton produced an extraordinary series of 'composite portraits', superimposing photographs of individuals to produce an image of a 'type' - in some cases a number of family members to produce an image of the typical features; in some, artistic geniuses; in other, more worrying examples, criminals or the chronically ill.

Byatt's work often uses the trope of portraiture; as in her superb extended lecture on Portraits in Fiction (200I); which ends with a meditation on the way she'd used the many portraits of Ash that Roland has collected in Possession. But it is there much earlier in her work too; in the prologue to the 1978 novel The Virgin in the Garden, set in the National Portrait Gallery in London in 1968, where Alexander has 
come to meet Frederica: 'He considered those words, once powerful, at present defunct, national and portrait. They were both to do with identity: the identity of a culture (place, language and history), the identity of an individual human being as an object for mimetic representation.' ${ }^{20}$

The relevance of these ideas to novelists as well as biographers is evident. Galtonian composite portraiture is a suggestive image in many ways. It connotes the way novelists combine traits of different real known people to create a new, unknown, opaque, person. It also suggests how biographers tessellate all the known reports and traces of their subject to try to create an impression of their existence. And more specifically in this case, it suggests how the trio of the three biographical subjects (or four, if you include Bole) can be superimposed to form a kind of composite portrait of the otherwise invisible biographer.

That invisibility or elusiveness of the subject - disappearing into the Maelstrom and frustrating the biographer's hopes of catching sight of his face - is one of the main advantages of the metabiographical approach. Where biofiction, like biography, tends to peddle the illusion that the real dead figure has been reanimated and made present, such metafictional labyrinths keep one aware of the difficulties biography or biofiction gloss over in their deceptions. What the focus on process makes us constantly aware of is the traces from which biography is constructed. And in the case of writers or thinkers like Linnaeus, Ibsen and Galton, as well as Henry James, what those traces mainly consist of is writing; especially their own writing.

That is why the synthesizing of texts by Ash and LaMotte was so important in Possession; not because the texts could be said to prove a relationship between these two figures previously unconnected by scholarship; not because texts would prove some kind of liaison existed outside the texts; but instead because the ways in which they wrote, including how they wrote to each other - in its ethical nuances, imaginative excitement, and attention to each others' words - is the most important thing about the relationship.

It is hard not to see Byatt's deeply sceptical position about biography as cautioning her readers, as well as any potential future biographers, against trying to read her own words biographically. Yet there is a story she has chosen to tell about herself, in the final book I want to mention by way of a conclusion: the marvellous Ragnarok of $20 \mathrm{II}{ }^{2 \mathrm{I}}$ In this book we do get glimpses of the author at a formative childhood 
moment. It is a portrait of the artist as a young woman. But the way she goes about it could not be further from Joyce's saturation in his own experience.

Ragnarok is a retelling of the Norse myth of the end of the world. In a sense it follows on from The Children's Book, not only because it is set in the Second World War, where that novel ended with the First. But because it summons back the book that meant the most to the author when she was a child: the Norse myth tales of Asgard and the Gods, given to her by her mother, to whom Ragnarok is dedicated.

To touch on biographical readings of Byatt like this is to introduce another dimension of life writing: the autobiographical. This may seem impertinent about a writer who has determinedly avoided the kind of narcissistic tendencies of postmodernism such as, say, including herself as a character in her own work (as writers from Martin Amis to Coetzee have done). Any autobiography in this book is refracted into the form of myth or folk tale. The stories are read by 'the thin girl' or 'the thin child' - that is the only way she is identified. Her father is away in the air force, and she does not expect him to return; the family are evacuated due to the bombing. One reason the Norse stories resonate is clearly because this child's world is destroying itself all around her; and the picture of a young mind beginning to comprehend the scale of that destruction is immensely poignant. ${ }^{22}$

But what also comes across so strongly is life. The descriptions of the weird life-forms assumed by the gods, and the teeming life of the countryside that absorbs the girl's attention, are overwhelming: they are mythology and the nature ramble reimagined through Darwin, as it were. Remember Linnaeus, the botanist, and the theme of bees and pollination in The Biographer's Tale. Or 'Morpho Eugenia' in Angels and Insects (I992) - which also contains excerpts from imagined works: the tract by Harald Alabaster, and the book on ants William Adamson is writing (with Matty Crompton).

Ragnarok thus shows the elemental aspect of creating life as well as destroying it. For Byatt it is not merely a matter of imagining a few human characters, but of imagining them in the context of all life; of the natural world, but also of the evolution of that world. Also, of course, she is highly aware of the threat to all life in the Anthropocene period, as the planet warms, bee numbers fall and human violence threatens ever new and lethal assaults on the environment. Life writing, 
for Byatt, that is, is about writing life in a much larger, more fundamental sense, than scrabbling about among people's laundry lists and family gossip.

But this is not to suggest that Byatt poses some form of vitalism against the artifices of literature. The focus of Ragnarok is not on the girl or her surroundings, as such. It is on stories. She reads fairy stories like Puss in Boots, or Greek Myths, but 'they didn't live in her, and she didn't live in them' ${ }^{23}$ Whereas the Norse stories do shape her view of the world in that internalizing way. When she gets to the story of Frigg asking everything in the world not to harm her son Baldur:

The thin child knew the promise could not hold. Something, somewhere, must have been missed, must have been forgotten. Stories are ineluctable. At this stage of every story, something must go wrong, be awry, whatever the ending to come [...] The goddess called everything, everything, to promise not to harm her son. Yet the shape of the story means that he must be harmed. ${ }^{24}$

And that is really the main autobiographical story of Ragnarok: not the girl's family, or the war even, though these things are its context; but the initiation into the world of stories, and especially to a sense of 'the shape of the story'. Ragnarok is not autobiography in any conventional sense; there is not enough of a childhood in it for it to be taxonomized as a childhood memoir even. But that phase in which the fictionality of stories becomes visible is crucial. The essential part of the story of most writers' autobiographies is how a reader becomes a writer. Even when she's not writing autobiographically, that sense of the shape of the story, and its story-ness always comes across very strongly in A. S. Byatt's work.

She has professed admiration for Thomas Mann's book about the process of composition: The Genesis of Doctor Faustus: The Story of a Novel. ${ }^{25}$ Henry James had written in his preface to The Ambassadors for the New York Edition of his novels and tales that 'There is the story of one's hero, and then, thanks to the intimate connexion of things, the story of one's story itself' ${ }^{26}$ The story of his stories is precisely what he tries to trace for his readers in the prefaces: their genesis from initial idea to elaborated work. For a creative writer that is the exciting story, the one worth telling. 
That reflexiveness about fiction is what makes these books of Byatt's doubly 'meta'; both metabiographical and metafictional. And to be able to tell biographical stories about biography that are also stories about stories and that are also such compelling novels is a truly extraordinary achievement.

\section{Notes}

I A. S. Byatt, Possession: A Romance (London, 1990).

2 See Laura Marcus, 'The Newness of the "New Biography", in Peter France (ed.), Mapping Lives: The Uses of Biography (Oxford, 2002) I93-2 I8.

3 The historiographic equivalent to this position is Hayden White's influential Metahistory: The Historical Imagination in Nineteenth-century Europe (Baltimore, 1973).

4 Max Saunders, Self Impression: Life-Writing, Autobiografiction and the Forms of Modern Literature (Oxford, 2010) $2 \mathrm{I}$.

5 Linda Hutcheon, A Poetics of Postmodernism (New York, London, I988) 5.

6 Linda Hutcheon, The Politics of Postmodernism (London, 1989) 57.

7 See Saunders, Self Impression, I9-2 I, 494-99.

8 See Saunders, 'Master Narratives', Cambridge Quarterly 37 (2008) I2 I-3 I.

9 See for example Jesse Matz, Lasting Impressions: The Legacies of Impressionism in Contemporary Culture (New York, 2017), Chapter 7.

Io Henry and Mary Garland, Oxford Companion to German Literature (Oxford, I976), 548.

I I Byatt's introduction to Ford's The Fifth Queen (1906-08) first appeared in the Twentieth Century Classics series (Oxford, I984), and was reprinted in the Penguin Modern Classics text of 1999.

I2 Alison Flood, 'Byatt attacks novelists who use real-life characters', Guardian (I3 August 2009); https://www.theguardian.com/books/2009/ aug/I3/byatt-novelists-real-life-characters (accessed I3 November 20I6).

I3 Ibid.

I4 William Archer, The Old Drama and the New: An Essay in Re-valuation (New Delhi, I923) 46: 'dramatists who could produce effects with such total disregard of nature, possibility and common-sense, worked in a soft medium which dispensed them from any approach to the outlay of intellectual energy involved in the construction of a good modern play. There is no art in invention when you are at liberty to invent nonsense'. 
I5 A. S. Byatt, Passions of the Mind: Selected Writings (London, I99I).

I6 Iris Murdoch, 'Against Dryness', Encounter (January I96I), I6-20, at 20. See Byatt, Passions of the Mind, 3.

I7 Murdoch, 'Against Dryness', 20.

I 8 A. S. Byatt The Biographer's Tale (London, 2000).

I9 Hermione Lee, 'Just get a life...: Have you read as widely as A. S. Byatt? If not, her new novel, The Biographer's Tale, will soon find you out', Guardian (28 May 2000), at https://www.theguardian.com/books/200o/ may/28/fiction.asbyatt, accessed I3 December 20 I 8.

20 A. S. Byatt, The Virgin in the Garden (London, I978) 9.

2 I A. S. Byatt, Ragnarok: The End of the Gods (London, 20 I I).

22 See Byatt, Passions of the Mind, 22-4, on this childhood story reading and storytelling.

23 Byatt, Ragnarok, 3I.

24 Byatt, Ragnarok, 89.

25 Thomas Mann, The Genesis of Doctor Faustus: The Story of a Novel, translated by R. Winston and C. Winston (New York, I96I). A. S. Byatt, Angermion lecture on Thomas Mann at the German Embassy, London, 3 December 2008.

26 Henry James, The Art of the Novel: Critical Prefaces, edited by R. P. Blackmur (Boston, I984) 3I3.

\section{About the Author}

Max Saunders is Director of the Arts \& Humanities Research Institute, Professor of English and Co-Director of the Centre for Life-Writing Research at King's College London. He is the author of Ford Madox Ford: A Dual Life (2 vols, Oxford University Press, 1996) and Self Impression: Life-Writing, Autobiografiction, and the Forms of Modern Literature (Oxford University Press, 20I0); and has edited several volumes of Ford's writings. In 2013 he was awarded an Advanced Grant from the ERC for a 5-year collaborative project on Digital Life Writing called 'Ego-Media'. E-mail: max.saunders@kcl.ac.uk 